\title{
Halloysite occurrence at the karstified contact of Oligocene sands and Cretaceous calcarenites in Hinnisdael quarries, Vechmaal (NE of Belgium)
}

\author{
Rieko ADRIAENS ${ }^{1 *}$, Benedicta RONCHI ${ }^{1,2}$, Gilles MERTENS $^{3}$, Sofie HOLLANDERS ${ }^{1}$, JAN ELSEN $^{1}$, Michiel DUSAR ${ }^{4}$ \\ \& NOËL VANDENBERGHE
}

\author{
${ }^{1}$ Department of Earth and Environmental Sciences, KU Leuven, Celestijnenlaan 200E, B-3001 Heverlee, Belgium. \\ ${ }^{2}$ Currently at ISSeP, Rue du Chéra, 4000 Liège, Belgium. \\ ${ }^{3}$ Qmineral Analysis \& Consulting- Gaston Geenslaan 1, 3001 Heverlee, Belgium. \\ ${ }^{4}$ Royal Belgian Institute of Natural Sciences - Geological Survey of Belgium, Jennerstraat 13, 1000 Brussel, Belgium. \\ *corresponding author: rieko.adriaens@ees.kuleuven.be; +3216326442.
}

\begin{abstract}
In Belgium, numerous karstified sand-carbonate contacts are known for their association with halloysite precipitation. In the Hinnisdael caves of Vechmaal, eastern of Belgium, a similar geological setting is observed in dolines of karstified calcarenite of the Cretaceous Maastricht Formation filled with sand of the Oligocene St. Huibrechts-Hern Formation. At the sand-calcarenite interface, a discontinuous succession occurs of white clay and oxidized rust almost perfectly segregated. These lithologies are authigenic precipitations of high purity consisting of only halloysite-allophane and goethite-ferrihydrite respectively. The Al, Si and Fe necessary for this precipitation were derived from the short-range distance dissolution of glauconite and other silicate minerals present in the overlying sand unit. The mobilization of these ions was realized by the progressive oxidation of pyrite to jarosite leading to a significant acidification of the percolating water. It is furthermore observed that seemingly small variations in local conditions in the Curfs quarry of Valkenburg, the Netherlands, result in alunite, gibbsite, halloysite, allophane precipitation instead of jarosite, halloysite-allophane and goethite-ferrihydrite.
\end{abstract}

KEYWORDS: Halloysite, allophane, karst, precipitation, Vechmaal.

\section{Introduction}

Halloysite is a dioctahedral 1:1 clay mineral of the kaolinite group frequently discussed in literature because of its potential for nanotechnological applications (Keeling, 2015; Yuan et al., 2015; Yuan et al., 2016). Its geological occurrence has been primarily linked to soil and weathering environments, by the weathering and alteration of volcanic rocks (Vaughan et al., 2002; Velde \& Meunier, 2008), the alteration of clay minerals like montmorillonite or biotite (Hill, 2000; Papoulis et al., 2009) or weathering of feldspars (Sheets \& Tettenhorst, 1997; Adamo et al., 2001). Halloysite is also a common mineral constituent in karst and paleokarst environments as a result of acid weathering (Polyak \& Güven, 2000; Joussein et al., 2005). In Belgium, halloysite was reported in over 30 localities, almost all with a very similar geological setting, i.e. karstified carbonate substrates filled up by Cenozoic sand deposits (Buurman \& Van der Plas, 1968; Dupuis \& Ertus, 1995; Goemaere \& Hanson, 1997;
Nicaise, 1998; Kloprogge \& Frost, 1999; De Putter et al. 2002; Bruyère, 2004).

A similar geological setting is found inside the underground quarries of Hinnisdael, locally known as "mergelgrotten" ("marl caves"), located in Vechmaal, Limburg province, Belgium (Fig. 1). In two of the Hinnisdael underground quarries, dolines filled with marine sand were intersected and an irregular white clay layer occurs at the contact between the karstified top of the Cretaceous calcarenites and Oligocene glauconiferous sands (see Table 1). These exceptionally well-preserved outcrops were reported by Dusar et al. (2005) who interpreted the white clay as an uneroded residue of Paleocene marls, in agreement with the geological map of Claes \& Gullentops (2001). Although these outcrops have never been studied in detail, the specific geological setting is nevertheless very suggestive for the presence of authigenic halloysite. The present paper therefore attempts to document the occurrence and mineralogy inside the doline and compare it with analogous sand - carbonate contacts.

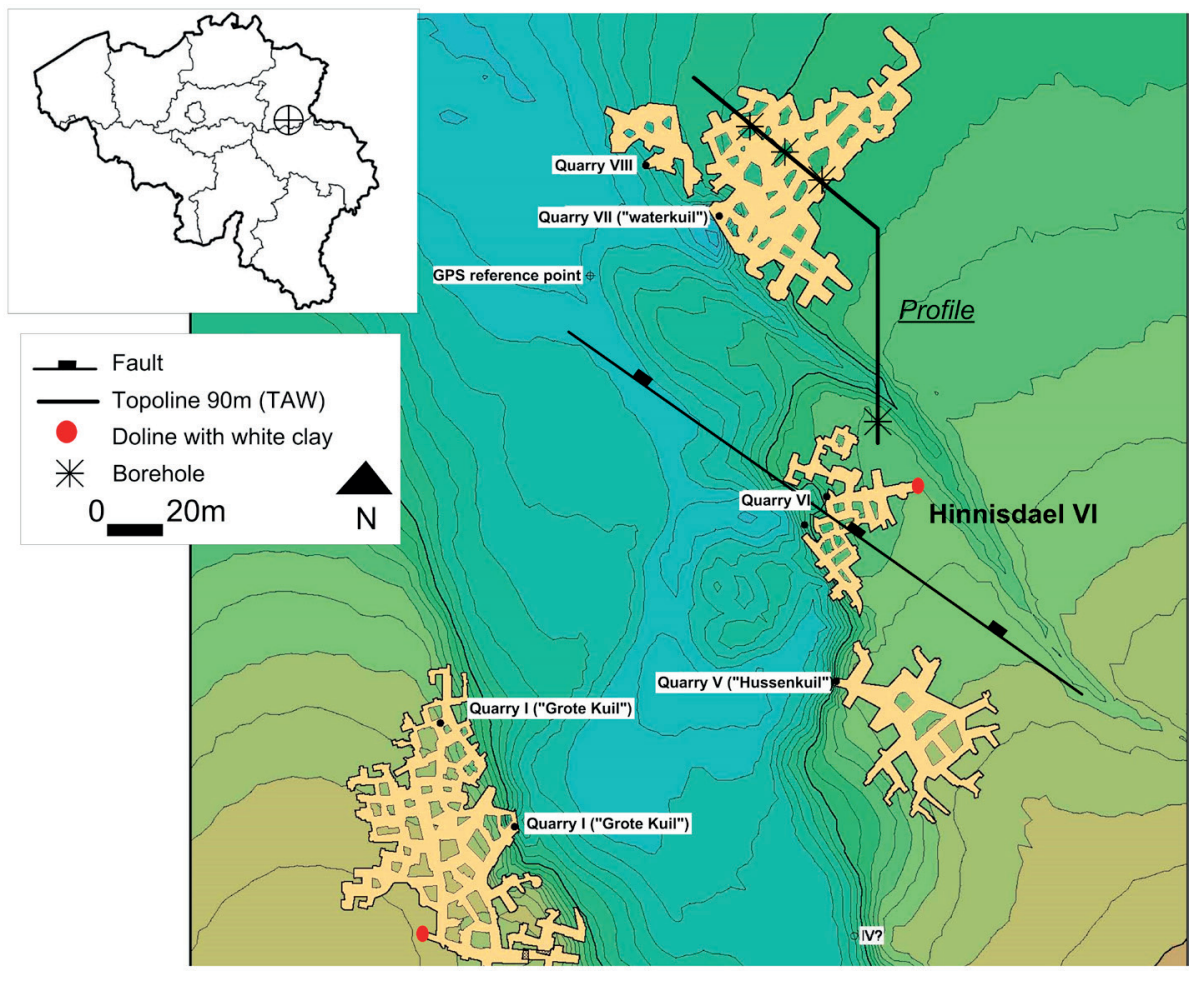

Figure 1. Digital Elevation Model and floor plan of part of the Hinnisdael underground quarries just south of the village Vechmaal (modified after Dusar et al., 2005). Location of white claybearing dolines (red dots) in quarry VI and quarry I ("Grote Kuil"), the profile line is shown in Figure 2. Coordinates of the GPS reference point: latitude 50.752130 , longitude 5.382616 . 


\begin{tabular}{|c|c|c|c|c|c|c|}
\hline \multicolumn{3}{|c|}{ Chronostratigraphy } & \multicolumn{3}{|c|}{ Lithostratigraphy } & \multirow{3}{*}{$\begin{array}{l}\text { Main lithology } \\
\text { glauconiferous sand }\end{array}$} \\
\hline System & Series & Stage & Group & Formation & Member & \\
\hline \multirow{3}{*}{ Paleogene } & Oligocene & Rupelian & Tongeren & Sint-Huibrechts-Hern & Grimmertingen & \\
\hline & \multirow{2}{*}{ Paleocene } & Selandian & Haine & Heers & $\begin{array}{l}\text { Gelinden } \\
\text { Orp }\end{array}$ & $\begin{array}{l}\text { white marl } \\
\text { glauconiferous sand }\end{array}$ \\
\hline & & Danian & Chalk & Houthem & Geulhem & calcarenite \\
\hline Cretaceous & Upper Cretaceous & Maastrichtian & & Maastricht & Nekum & calcarenite \\
\hline
\end{tabular}

Table 1. Stratigraphic succession of the different lithological units discussed in this paper.

\section{Geological setting}

The underground quarries of Hinnisdael are located in the village of Vechmaal, at $7 \mathrm{~km} \mathrm{SW}$ of Tongeren (South Limburg, Belgium; Fig. 1). The quarries were excavated around a topographical depression in the Maastricht Formation consisting of a soft fossiliferous calcarenite. Calcarenite was primarily exploited for its use as building stone, later on also as a conditioner for the heavy loamy soil. Historical research suggests that the most intensive extraction of building blocks occurred around the $14-15^{\text {th }}$ century (Dusar et al., 2005). Today, eight separate underground networks — named "caves" in the regional vernacular language — are still known to exist in Vechmaal.

The Cretaceous calcarenite is covered by Oligocene sands of the Sint-Huibrechts-Hern Formation. The entire succession is overlain by Quaternary loess deposits turned into loam (Fig. 2). On the 1:50 000 geological map, the Paleocene sands and marls of the Heers Formation are represented as a stratiform unit in between the Oligocene and Cretaceous deposits (Claes \& Gullentops, 2001) (Table 1). According to Dusar et al. (2005), this unit would be reduced to isolated erosion residues observed in some quarries. A NW-SE fault with total vertical throw of 6 $\mathrm{m}$ passing across the entrance of the Hinnisdael VI quarry was mapped by Dusar et al. (2005) (Fig. 1). Small-scaled faults and joints can be observed in these quarries, testifying of postOligocene tectonic activity related to the vertical movements of the London-Brabant massif basement and the opening of the Ruhr Valley Graben.

The top of the calcarenite is slightly karstified and deep dolines filled with Grimmertingen sands of the Oligocene SintHuibrechts-Hern Formation can be observed in different quarry walls (see Dusar et al., 2005 for morphology, Willems et al., 2007 for regional synthesis). Although similar features occur in other quarry dolines, in this work only the most representative doline outcrop in the far north-east corner of the Hinnisdael VI cave is analyzed in detail (Fig. 1).

The doline outcrop of the Hinnisdael VI quarry consists of two main lithologies, namely the glauconite-bearing sands, assigned to the Grimmertingen Member of the Sint-Huibrechts-Hern Formation (Gr. sands in Fig. 3) covering the homogeneous pale and fine-grained calcarenites, assigned to the Nekum Member of the Maastricht Formation (Dusar et al., 2005; Dusar \& Lagrou, 2007; Calc. in Fig. 3). The slightly glauconiferous Grimmertingen sands are medium- to fine-grained with a relatively high dispersed clay content but also cm-thick clay lenses are common. Pelletal glauconite contents typically are in the range of 2 to $5 \%$. The grey-green sand is clearly oxidized leaving rust-brown oxidation spots or lineations, as remnants of fluctuating water levels inside the cave. Such oxidation also occurs locally in the calcarenite.

The contact between calcarenite and sand is irregular due to formation of a karstic solution doline, displaying different lithologies and textures. Most prominent are the stiff discontinuous white clay layer and a rusty-brown colored layer forming the transition from calcarenite to sand (respectively W.C. and R.S. in Fig. 3).

The white clay generally occurs on top of the rusty layer and both lithologies are very variable in thickness, from 1 to 40 centimeters. Additionally, the lithological contacts of both layers are very irregular and often the contact is toothed or incised on a mm-scale, as commonly described on dissolution surfaces. An undisturbed, four-layer sequence is rarely observed since several fractures, post-sedimentation displacements and collapse features can be identified in the outcrop (Fig. 3B). Locally, the sand-calcarenite contact is so much disturbed that small patches of calcarenite and brecciated clasts of white clay can be observed interbedded with rusty-brown and grey-green sands (Fig. 3E).

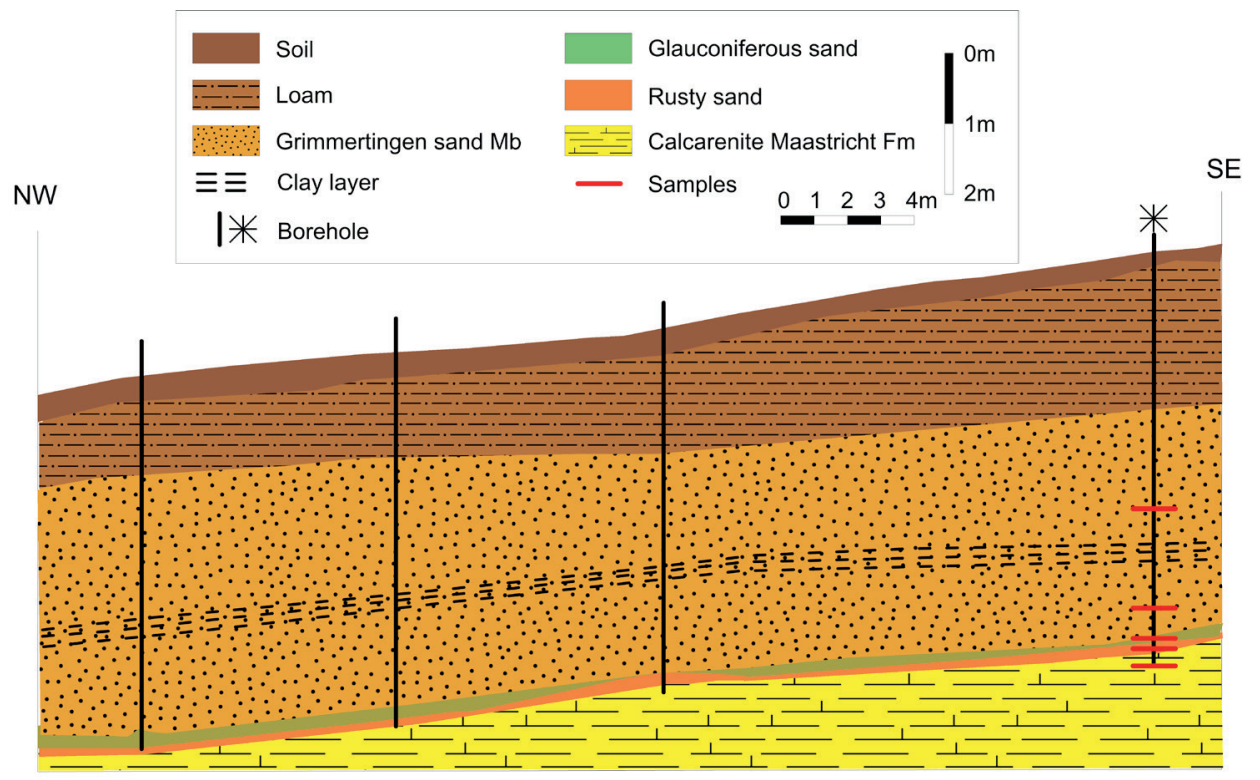

Figure 2. NW-SE profile of the geological subsurface from Waterkuil to Hinnisdael VI quarries based on auger boreholes (position of the profile is shown in Figure 1). Samples were collected from the southernmost borehole located near Hinnisdael VI quarry. 


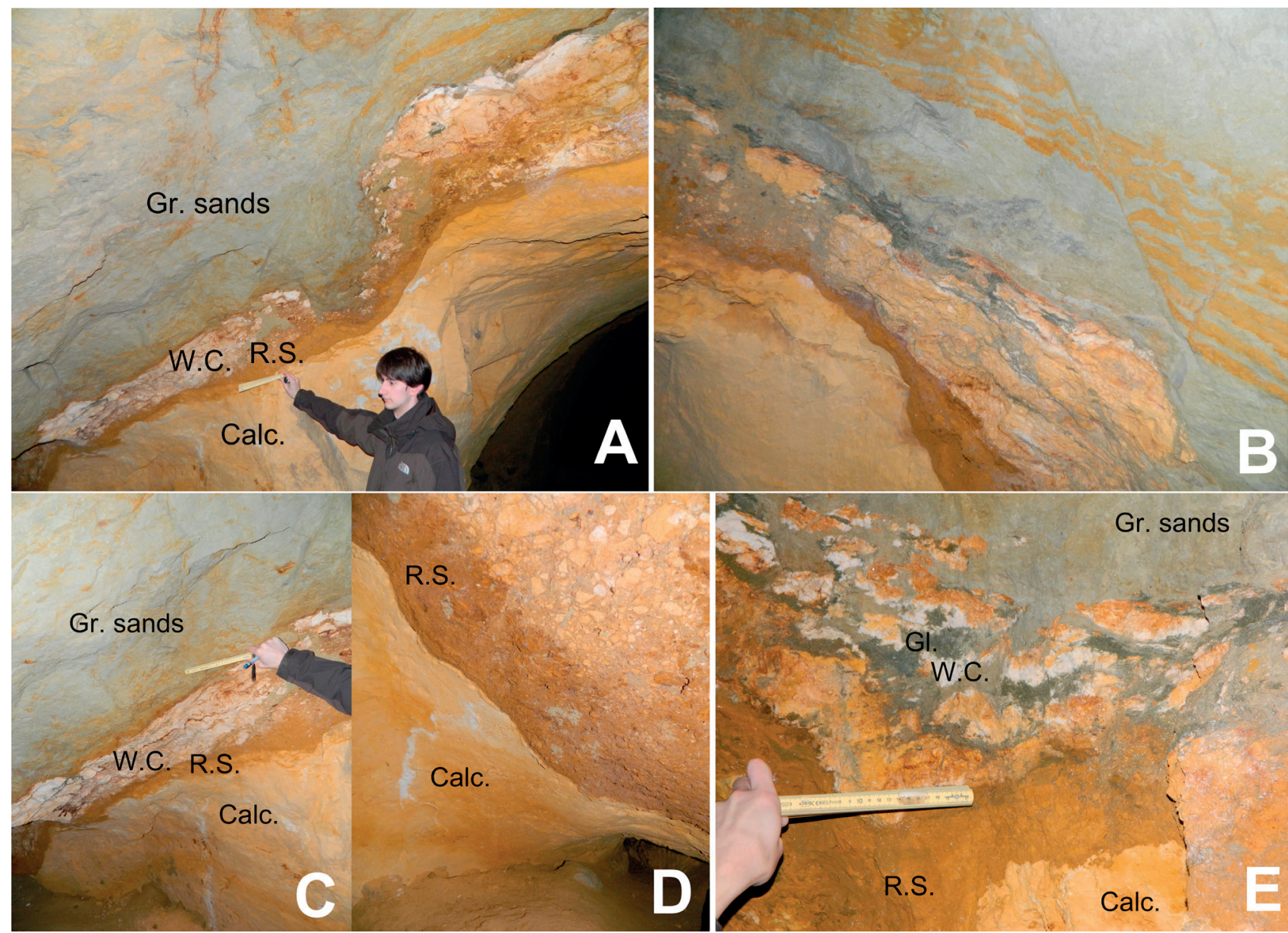

Figure 3. (A) Stratigraphic succession in the Hinnisdael VI doline. "Gr. sands"= Grimmertingen sands of the Sint-Huibrechts-Hern Formation; "W.C."= White clay; "R.S."= Rusty sand; "Calc."= Calcarenite of the Maastricht Formation. (B) Secondary displacement and faulting in the Grimmertingen sands marked by linear oxidation tracks. (C) Stratigraphic succession of the Hinnisdael VI cave. White clay has percolated through the calcarenite (vertical white lines at bottom). (D) Brecciation in the Hinnisdael VI doline. (E) Detailed photograph of disturbed stratigraphic succession at the sand-calcarenite contact with the presence of dark green, glauconite-rich patches indicated by "Gl." and white clay "W.C.".

Isolated, glauconite-rich patches and spots also occur at the contact, sometimes oxidized, but never occur as a continuous layer in outcrop. White clays can also be observed as near-vertical elongated strings in the underlying calcarenite, filling secondary porosity dissolution voids (Fig. 3C).

A series of boreholes was augered above the Waterkuil and the Hinnisdael VI quarries following a NW-SE trajectory (Figs 1, 2). Typically, the Oligocene Grimmertingen sands are found below 1-2 $\mathrm{m}$ of Quaternary loam. At the contact with the calcarenite, a few centimeters of dark green glauconite-rich sands and/or orange-colored sands are present, underlying a clayey intercalation which plays a preponderant role in retarding the vadose circulation (Ronchi, 2009). Such a glauconite-rich layer was not encountered inside the doline but highly resembles the green glauconite-rich patchy material found in the doline (Fig. 3 ). Based on the assumption that the white clay corresponds to the stratiform Gelinden marl, this glauconite-rich sand was tentatively assigned to the Paleocene Orp sands underlying the Gelinden marls by Dusar et al. (2005). The orange-colored sands have a more intense orange color compared to the rusty-brown color encountered in the doline. Although no white clay was found in the borehole above the Hinnisdael VI quarry, some white clay enrichments were encountered in the boreholes overlying the Waterkuil quarry (Ronchi, 2009) (Fig. 2).

\section{Materials \& methods}

Samples of the different lithologies were collected in the Hinnisdael VI cave (Fig. 3), i.e. the glauconiferous Grimmertingen sands, white clays, rusty-brown sands, dark green sands and finally the calcarenites. Additionally, samples of the main lithologies from the southernmost borehole above the Hinnisdael VI quarry were collected (Fig. 2). For reasons of comparison, two additional samples of the Heers Formation were included, one of the Gelinden marls and one of the Orp sands, both from the KU Leuven stratigraphical collection. Mineralogical characterization was performed on all samples, thermal and chemical characterization was focused on the white clay.

For mineralogical characterization, XRD measurements were carried out on random oriented powders. Samples were mixed with an internal standard, $\mathrm{ZnO}$, and wet milled for 5 min using a McCrone micronizing mill. To obtain optimal random orientation of the crystallites, powders were side-loaded into alumina measurement holders (after Środoń et al., 2001; Snellings et al., 2010). XRD measurements were executed on a Phillips PW1830 diffractometer with Bragg-Brentano setup equipped with $\mathrm{Cu}-\mathrm{K} \alpha$ radiation, a graphite monochromator and gas proportional detector. Measurements were recorded at 45 $\mathrm{kV}$ and $30 \mathrm{~mA}$ from $5-65^{\circ} 2 \theta$ with $0.02{ }^{\circ} 2 \theta$ step size and $2 \mathrm{~s}$ counting time. Interpretation and quantification were performed using the pattern summation Quanta software (C) Chevron ETC). In this software, all identified mineral phases are quantified as a summation of pure mineral standards, previously recorded on the same diffractometer (Adriaens, 2015).

The detailed clay mineralogy was determined on oriented clay slides which were first chemically prepared to remove aggregate-forming particles (after Jackson, 1975) combined with ultrasonic treatment. Afterwards, clay fractions were separated using centrifugation and saturated with $\mathrm{CaCl}_{2}$ to make $\mathrm{Ca}^{2+}$ the exchangeable cation. The clay powders were sedimented on small glass plates and measured in air dry conditions, after ethylene glycol solvation and after heating at $550^{\circ} \mathrm{C}$ for $1 \mathrm{~h}$ environments using the PW1830 diffractometer $\left(2-47^{\circ} 2 \theta, 0.02^{\circ} 2 \theta\right.$ step size, $2 \mathrm{~s}$ counting time). Sybilla clay modeling software (C) Chevron ETC) was used for interpretation and quantification. 


\begin{tabular}{|c|c|c|c|c|c|c|c|c|c|c|c|c|c|c|}
\hline \multirow[t]{2}{*}{ Hinnisdael VI - Doline } & \multirow{2}{*}{$\begin{array}{c}\text { Sample } \\
\text { Code }\end{array}$} & \multicolumn{6}{|c|}{ Regular phases } & \multicolumn{4}{|c|}{ Clay minerals } & \multicolumn{3}{|c|}{ Poorly-crystalline phases } \\
\hline & & $\begin{array}{c}\text { Quartz } \\
(\%)\end{array}$ & $\begin{array}{c}\text { K-Feldspar } \\
(\%)\end{array}$ & $\begin{array}{c}\text { Plagioclase } \\
(\%) \\
\end{array}$ & $\begin{array}{c}\text { Jarosite } \\
(\%)\end{array}$ & $\begin{array}{c}\text { Calcite } \\
(\%)\end{array}$ & $\begin{array}{c}\text { Goethite } \\
(\%)\end{array}$ & $\begin{array}{c}\text { Kaolinite } \\
(\%) \\
\end{array}$ & $\begin{array}{c}\text { Halloysite } \\
(\%)\end{array}$ & $\begin{array}{c}\text { 2:1 Al-clay } \\
(\%)\end{array}$ & $\begin{array}{c}\text { Glauconite } \\
(\%) \\
\end{array}$ & $\begin{array}{c}\text { Allophane } \\
(\%)\end{array}$ & $\begin{array}{c}\text { Ferrihydrite } \\
(\%)\end{array}$ & $\begin{array}{c}\text { Opal - CT } \\
(\%) \\
\end{array}$ \\
\hline \multirow{4}{*}{ Grimmertingen sand $\mathrm{Mb}$} & RAD12 & 64 & 11 & & 2 & & & 4 & & 17 & 2 & & & \\
\hline & RAD13 & 63 & 10 & & 1 & & 7 & 1 & & 14 & 4 & & & \\
\hline & RAD15 & 67 & 8 & 1 & 2 & & 2 & 3 & & 14 & 3 & & & \\
\hline & RAD17 & 70 & 11 & 1 & & & 0.4 & 2 & & 14 & 2 & & & \\
\hline Clay lense & RAD48 & 7 & 5 & & 8 & & & 7 & & 73 & & & & \\
\hline Clay lense & RAD49 & 10 & 5 & & 5 & & & 6 & & 74 & & & & \\
\hline \multirow{2}{*}{ Dark green patches } & RAD14 & 49 & 4 & 1 & & & 6 & 3 & & 17 & 20 & & & \\
\hline & RAD10 & 61 & 3 & & & & 3 & 1 & & 8 & 24 & & & \\
\hline \multirow{7}{*}{ White clay } & RAD11 & 10 & & & & & 2 & & 58 & & & 30 & & \\
\hline & RAD16 & 3 & & & & & 1 & & 59 & & & 37 & & \\
\hline & RAD19 & 2 & & & & & 2 & & 51 & & & 45 & & \\
\hline & RAD21 & 1 & & & & & & & 62 & & & 37 & & \\
\hline & RAD23 & 4 & & & & & & & 63 & & & 33 & & \\
\hline & RAD24 & 1 & & & & 1 & 1 & & 56 & & & 41 & & \\
\hline & RAD25 & 1 & & & & & 1 & & 62 & & & 36 & & \\
\hline \multirow{2}{*}{ Rust-colored layer } & RAD18 & 12 & 2 & & & & 65 & & & & & & 21 & \\
\hline & RAD32 & 2 & & & & & 73 & & & & & & 25 & \\
\hline \multirow{2}{*}{ Calcarenite } & RAD31 & 2 & & & & 98 & & & & & & & & \\
\hline & RAD20 & 2 & & & & 98 & & & & & & & & \\
\hline \multicolumn{15}{|l|}{ Borehole outside doline } \\
\hline Grimmertingen & RAD46 & 62 & 5 & & 3 & & & 5 & & 23 & 2 & & & \\
\hline sand $\mathrm{Mb}$ & RAD39 & 71 & 13 & & 2 & & & 2 & & 10 & 2 & & & \\
\hline Glauconite-rich sand & RAD53 & 55 & 5 & 1 & & & & & & 17 & 22 & & & \\
\hline Orange-rusty sand & RAD54 & 21 & & & & & 3 & & 7 & 3 & & 13 & 53 & \\
\hline Calcarenite & RAD56 & 1 & & & & 99 & & & & & & & & \\
\hline Reference & Gelinden & 1 & & & & 87 & & & & 7 & & & & 5 \\
\hline Heers Fm & Orp & 52 & 6 & & & & & 3 & & 20 & 19 & & & \\
\hline
\end{tabular}

Table 2. Bulk mineralogical composition of different lithologies in the Hinnisdael VI quarry and in the borehole above the Hinnisdael VI quarry. The group 2:1 Al-clay consists of the layer silicates smectite, illite and randomly interstratified illite-smectite and muscovite.

In order to characterize the thermal behavior of the white clay, oriented slides were prepared by smearing $200 \mathrm{mg}$ of untreated, moist white clay directly from the sample bag on a glass slide and subsequently without further drying measured with XRD with the same conditions as the clay powders $\left(2-47^{\circ} 2 \theta, 0.02^{\circ} 2 \theta\right.$ step size, $2 \mathrm{~s}$ counting time). After, the clay slide was left drying to normal room conditions and again measured successively after $2 \mathrm{~h}, 4 \mathrm{~h}$, $8 \mathrm{~h}$ and $24 \mathrm{~h}$ of drying using the same instrumental conditions. Additionally, a thermal characterization using a Netsch STA 409PC instrument with simultaneous Thermogravimetric analysis (TGA) and Differential Scanning Calorimetry (DSC) recordings was used. The sample was heated in $\mathrm{Al}_{2} \mathrm{O}_{3}$ crucibles from $25^{\circ} \mathrm{C}$ to $1000{ }^{\circ} \mathrm{C}$ with a heating rate of $10{ }^{\circ} \mathrm{C} / \mathrm{min}$ in a $\mathrm{N}_{2}$ atmosphere with a $60 \mathrm{ml} / \mathrm{min}$ flux.

Major element analysis was performed to characterize the white clay using $\mathrm{LiBO}_{2}$ fusion for digestion and Inductive Coupled Plasma Optical Emission Spectrometry (ICP-OES) measurement (after Suhr \& Ingamells, 1966).

\section{Results}

\subsection{Mineralogy}

The results of the X-ray diffraction analysis on random oriented bulk powders (Table 2) show that the Oligocene Grimmertingen Member is a clayey sand unit with frequently occurring clay lenses. Both sand and clay have a very stable bulk mineralogical composition. The clay lenses consist of $80 \%$ clays, $7-10 \%$ quartz, $5 \% \mathrm{~K}$-feldspar and remarkably high amounts $(5-8 \%)$ of jarosite $\left(\mathrm{KFe}_{3}^{3+}\left(\mathrm{SO}_{4}\right)_{2}(\mathrm{OH})_{6}\right)$. The sand is very rich in quartz $(60-70 \%)$ but also contains clays (15-20\%) and K-feldspar (ca. 10\%). The glauconite content is fairly low $(<5 \%)$ and occasionally low amounts $(<1 \%)$ of jarosite are present. The mineralogy of Grimmertingen sands in the borehole is very similar (Table 2).

The mineralogy of the dark green patches, occurring at the base of the sand is similar to that of the Grimmertingen sands but contains significant more glauconite $(>20 \%)$. This mineralogical composition is also found at the sand-calcarenite contact in the borehole and furthermore matches with the typical composition of the Orp sand Member of the Heers Formation.
The mineralogy of the white clay in the doline is typically formed by a mixture of halloysite and the semi-crystalline phase allophane (Fig. 4). The presence of halloysite is suggested by its (001) position at ca. $7.4 \AA\left(11.94{ }^{\circ} 2 \theta\right)$, at a slightly higher angle compared to the $7.16 \AA\left(12.36^{\circ} 2 \theta\right)$ typical for the (001)-reflection of kaolinite. Diffraction of halloysite is typically characterized by much reduced coherent scattering domain sizes compared to the more crystalline kaolinite, resulting in significantly less sharp diffraction peaks for halloysite. The presence of halloysite was proven by its thermal behavior during detailed clay analysis (see further). Allophane is identified by two separate broad bumps, one at $3.4 \AA\left(26.20^{\circ} 2 \theta\right)$ and one at $2.25 \AA\left(40.06^{\circ} 2 \theta\right)$, being the typical diffraction maxima for hydrous aluminosilicates like allophane and imogolite (Fig. 4).

The rust colored layer below the white halloysite in the doline consists dominantly of goethite and a badly crystalline to amorphous phase. The amorphous phase was identified as ferrihydrite (2-line) based on diffraction bumps at $2.6 \AA$ (34.46 $\left.{ }^{\circ} 2 \theta\right)$ and one at $1.5 \AA\left(61.84^{\circ} 2 \theta\right)$ (Fig. 5). The orange-rust colored sand at the sand-calcarenite interface in the borehole contains high amounts of ferrihydrite (53\%) and allophane (13\%). Additionally also a small amount of halloysite was found (7\%) which indicates that halloysite also occurs outside of the doline but less massively. The calcarenite finally is almost monomineralic, predominantly consisting of calcite.

\subsection{Clay mineralogy}

The clay mineralogy $<2 \mu \mathrm{m}$ of the Oligocene Grimmertingen sands were determined both on the clayey sand samples as on individual clay lenses. Clay modeling with the Sybilla software points out that the clay mineral assemblage in and outside the dolines is very consistent throughout the unit (Table 3). Typically, the clay assemblage consists of $60-69 \%$ smectite, $15-20 \%$ randomly interstratified mixed-layered illite-smectite, 6-9\% kaolinite and $6-12 \%$ illite. Clay lenses seem to be the most smectite-rich.

The green glauconite-rich patches at the base of the sand contain less smectite and regularly interstratified mixed-layered glauconite-smectite is incorporated in the $<2 \mu \mathrm{m}$ fraction which explains the dark green color of the sediment (Adriaens et al., 2014). 


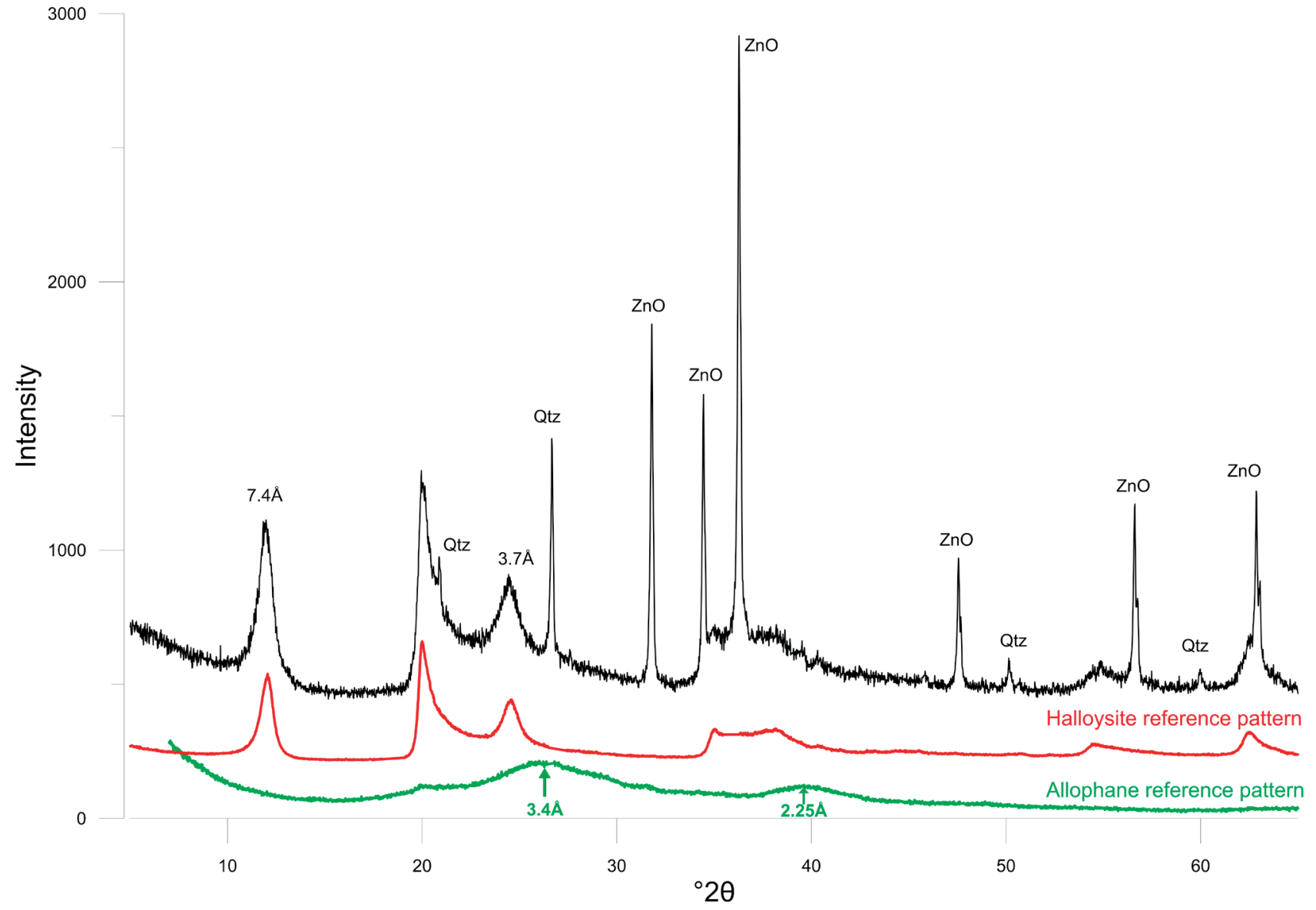

Figure 4. Powder diffraction pattern of the white clay with $\mathrm{ZnO}$ as internal standard. Halloysite (red) and allophane (green) reference patterns are shown at the bottom.

This clay assemblage is very similar to that of the reference sample of the Orp sand Member (Heers Fm). Visual inspection of the diffraction patterns of the white clay shows that no other traceable clay minerals are found above the detection limit of ca. $1 \%$. The clay mineralogy of the reference sample of the Gelinden marls (Heers Fm) is significantly different, consisting of $80 \%$ smectite and is furthermore characterized by the absence of kaolinite.

\subsection{Thermal characterization of halloysite}

Halloysite is a unique member of the dioctahedral 1:1 kaolin group since its structure incorporates one layer of water between the typical tetrahedral-octahedral layered structure. As a result, the size of the unit cell is $10 \AA$ in the $c$-direction. However, the monolayer of water is very easily destabilized upon dehydration, resulting in a $d_{001}$ of $7.3 \AA$ to $7.4 \AA$ (Joussein et al., 2005). During X-ray powder diffraction analysis, which involves a drying procedure at $60{ }^{\circ} \mathrm{C}$, it was systematically observed that halloysite occurred in its dehydrated $7 \AA$ state. Nevertheless, the hydrated $10 \AA$ form is positively identified when a wet smear slide is prepared before any drying and immediately measured (Fig. 6). Subsequently, the wet smear slide was left to dry in open air and measured again after 2 $\mathrm{h}, 4 \mathrm{~h}, 8 \mathrm{~h}$ and $24 \mathrm{~h}$. Already after $2 \mathrm{~h}$, the $10 \AA$ phase starts to form and coexists with the $7.4 \AA$ phase (Fig. 7). After $24 \mathrm{~h}$ of normal room conditions, dehydration was already fully achieved resulting in a $7.4 \AA$ monophase in XRD patterns.

The thermal behavior of the halloysite was also tested using a simultaneous TGA-DSC analysis. The typical thermal signal for halloysite is characterized by three distinct thermal events (Joussein et al., 2005). Analysis of the white clay shows a first endothermic reaction occurs at $105.6{ }^{\circ} \mathrm{C}$ corresponding to the dehydration of adsorbed water (Fig. 8). A second endothermic reaction takes place at $487.3{ }^{\circ} \mathrm{C}$, which represents the dehydroxylation reaction of halloysite. An exothermic reaction is observed at high temperatures $\left(980^{\circ} \mathrm{C}\right)$ when new mineral phases are being formed (Fig. 8). The thermal pattern furthermore shows an additional exothermic reaction at $561.6^{\circ} \mathrm{C}$, which is caused by the transformation of allophane into a crystalline phase (Fields \& Claridge, 1975; White, 1979).

\subsection{Chemistry of the white clay}

The ICP-OES analysis of three white clay samples shows little variation. The chemical composition of the white clay consists of mainly $\mathrm{SiO}_{2}(38-40 \%), \mathrm{Al}_{2} \mathrm{O}_{3}(34-37 \%)$ and minor $\mathrm{Fe}_{2} \mathrm{O}_{3}$

\begin{tabular}{|c|c|c|c|c|c|c|}
\hline Clay mineralogy $<2 \mu \mathrm{m}$ & Code & $\begin{array}{c}\text { Smectite } \\
(\%)\end{array}$ & $\begin{array}{c}\text { Illite/smectite } \\
(63 / 37) \\
(\%)\end{array}$ & $\begin{array}{l}\text { Illite } \\
(\%)\end{array}$ & $\begin{array}{c}\text { Kaolinite } \\
(\%)\end{array}$ & $\begin{array}{c}\text { Glauconite/smectite } \\
(89 / 11) \\
(\%)\end{array}$ \\
\hline \multirow{4}{*}{ Grimmertingen sand $\mathrm{Mb}$} & RAD12 & 60 & 19 & 12 & 9 & \\
\hline & RAD13 & 67 & 20 & 7 & 6 & \\
\hline & RAD15 & 65 & 17 & 10 & 8 & \\
\hline & RAD17 & 62 & 19 & 10 & 9 & \\
\hline Clay lense & RAD48 & 69 & 15 & 9 & 7 & \\
\hline Clay lense & RAD49 & 69 & 18 & 6 & 7 & \\
\hline Glauconite-rich sand & RAD53 & 47 & 31 & 6 & 1 & 15 \\
\hline Reference & Gelinden & 80 & 17 & 3 & & \\
\hline Heers Fm & Orp & 56 & 21 & 7 & 6 & 10 \\
\hline
\end{tabular}

Table 3. Clay mineralogical composition of different lithologies in the Hinnisdael VI quarry. 


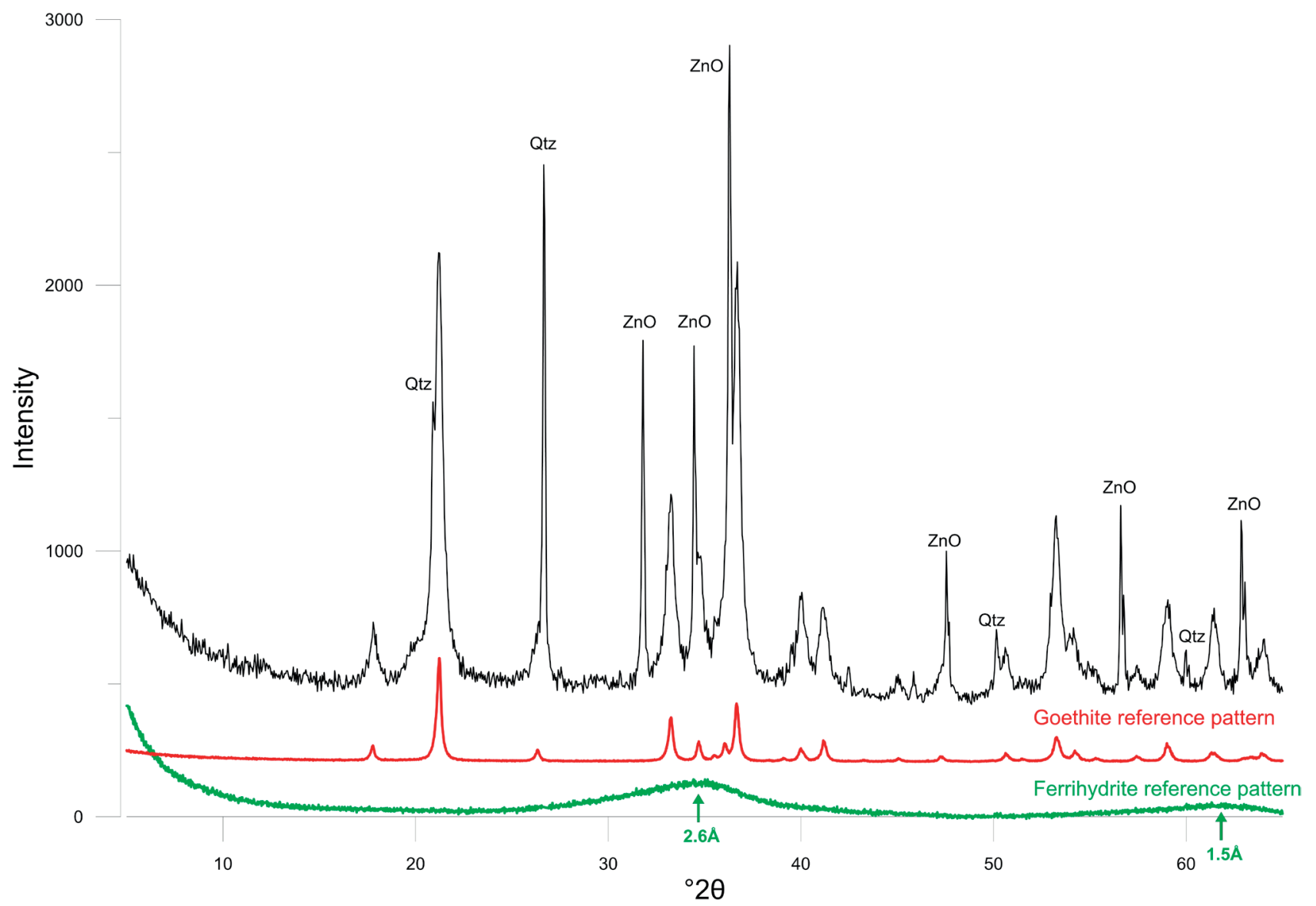

Figure 5. Powder diffraction pattern of the rusty sand with $\mathrm{ZnO}$ as internal standard. Goethite (red) and ferrihydrite (green) reference patterns are shown at the bottom.

$(0.5-1.6 \%)$ and $\mathrm{CaO}(1.1-1.6 \%)$ (Table 4). Joussein et al. (2005) reviewed published chemical data of halloysites and concluded that the ideal structural formula is $\mathrm{Al}_{2} \mathrm{Si}_{2} \mathrm{O}_{5}(\mathrm{OH})_{4} \cdot \mathrm{nH}_{2} \mathrm{O}$ (Bailey, 1980). However, the majority of halloysites also contains significant proportions of $\mathrm{Fe}^{3+}$ due to the isomorphous substitution of $\mathrm{Fe}^{3+}$ for $\mathrm{Al}^{3+}$ in the octahedral sheet. Allophanes are reported with $\mathrm{SiO}_{2} / \mathrm{Al}_{2} \mathrm{O}_{3}$ ratios of 1.5 to 2 . Since both halloysite as well as allophane have variable compositions, no structural formulas could be calculated. The $\mathrm{CaO}$ contribution might originate from the interlayer water in the halloysite structure or more likely by the presence of finely dispersed calcite dust.

\section{Discussion}

\subsection{Stratigraphy}

In the Hinnisdael VI doline, some lithologies were found at the sand-calcarenite interface which cannot simply be assigned to neither the Grimmertingen sands, nor to the Maastricht calcarenites. At the base of the sands, dark green patches were encountered with elevated glauconite contents which are atypical for the Grimmertingen sands. Although the occurrence of a glauconite-rich basal interval is a typical feature for many marine

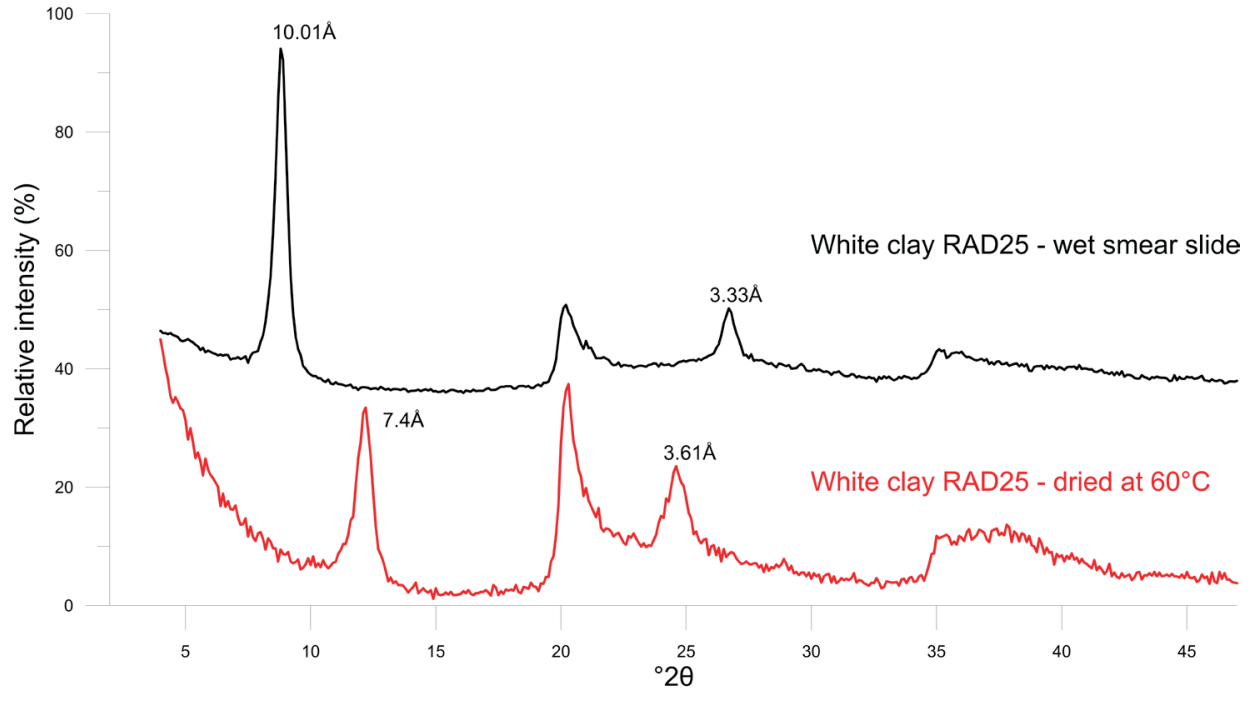

Figure 6. Diffraction patterns of white clay in moist conditions (black) showing the fully hydrated $10 \AA$ halloysite and after oven-drying at $60{ }^{\circ} \mathrm{C}$ (red) showing dehydrated $7 \AA$ halloysite. 


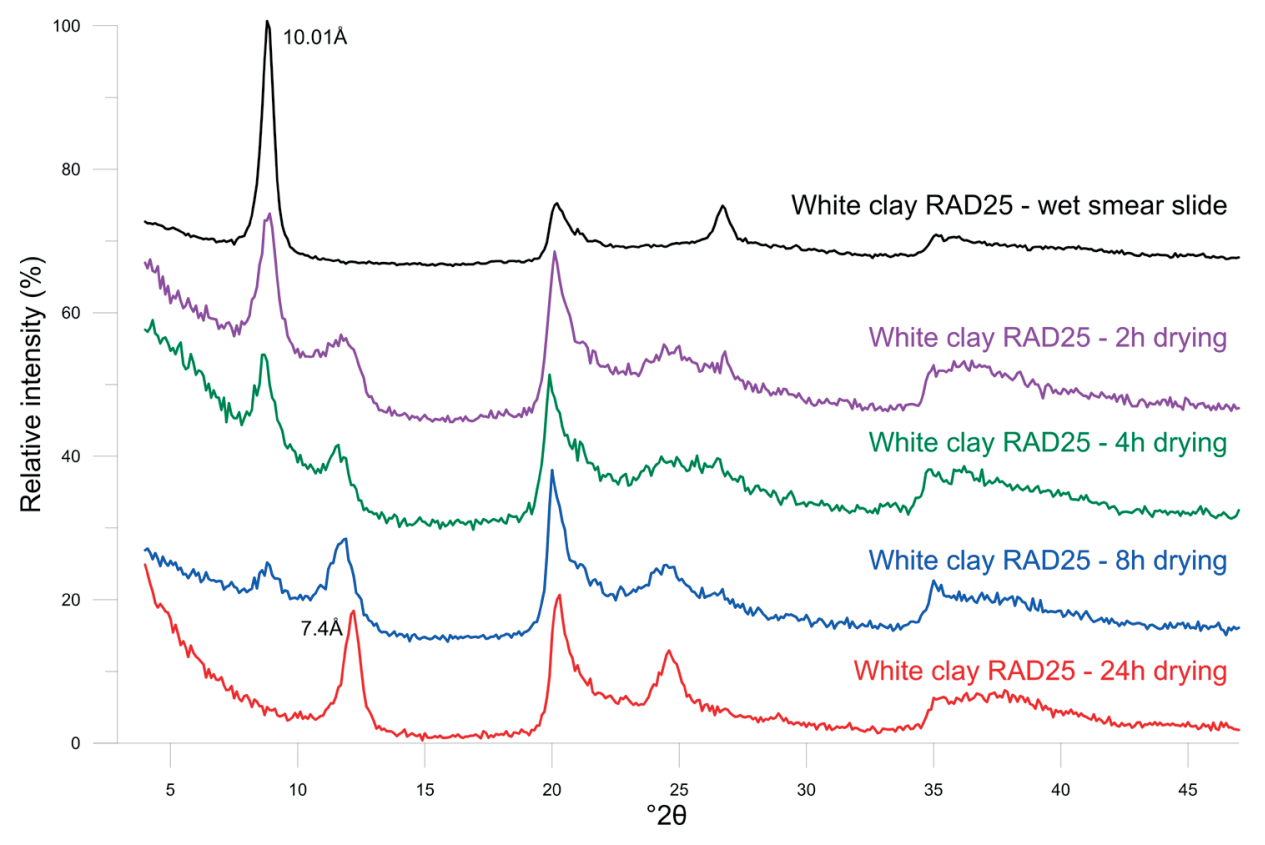

Figure 7. Diffraction patterns of white clay indicating the evolution of fully hydrated $10 \AA$ halloysite to dehydrated $7 \AA$ halloysite after air-drying at room conditions with XRD measurements during regular intervals.

transgressive Cenozoic sand units in Belgium, such a glauconiterich base interval for the Grimmertingen sand Member has never been reported. A glauconite-enriched sand sediment is however typical for the Orp sand Member of the Paleocene Heers Formation, of which the presence in the area and even on-site was already suggested by Claes \& Gullentops (2001) and Dusar et al. (2005). The Orp sand origin of the glauconite-rich sediment seems to be supported by the mineralogical and clay mineralogical analyses of the reference sample (Tables 2, 3). The new mineralogical analyses also show that the white clay cannot be a remnant of the Gelinden marls of the Heers Formation. Misinterpreting the stiff white clays as Gelinden marls is at the origin of erroneous stratigraphical succession and geological mapping. The nature of the minerals identified at the karst-wall interface, the high degree of purity of both the halloysite-allophane and the goethite-ferrihydrite layers combined with their segregated and discontinuous occurrence in the dolines, strongly support the idea that these minerals are post-depositional authigenic precipitates and therefore have no stratigraphic significance.

\subsection{Formation of halloysite-allophane and goethite-ferrihydrite}

Although the coexistence of halloysite and allophane has been recognized in volcanic soil studies (Sherman, 1952; Chorover et al., 1999; Keeling, 2015), halloysite is commonly described as a precipitate in karst and paleokarst environments (Polyak \& Güven, 2000; Joussein et al., 2005). The formation of halloysite is regularly described as the result of intensive weathering and leaching of alumina and silica from paleosoils (Buurman et al., 1975) or from overlying glauconitic formations (Baioumy \& Hassan, 2004). The precipitation at the Hinnisdael VI sandcalcarenite contact can be explained by a similar model. Both precipitation lithologies have been formed as the result of meteoric waters percolating through the glauconitic sand units followed by precipitation at the contact with the calcarenite. The considerable amounts of jarosite and goethite in the Grimmertingen sand Member (Table 4) strongly suggest an important pyrite oxidation. Such progressive oxidation of pyrite in these glauconitic units resulted in a significant acidification of the percolating water. The acidic water caused dissolution and mobilization of $\mathrm{Al}, \mathrm{Si}$ and $\mathrm{Fe}$ present in silicate minerals until the sand-calcarenite contact, which acts as a $\mathrm{pH}$ barrier. Due to the contact with the carbonate, pore water $\mathrm{pH}$ recovers towards higher values, resulting in oversaturation and precipitation. It is likely that the first precipitation is that of very fine amorphous and semi-crystalline gels, like ferrihydrite and allophane, since their nucleation is kinetically favored over that of crystalline phases (Ugolini \& Dahlgren, 2002). According to Van Breemen \& Buurman (2002) oversaturation towards Fe-oxyhydroxides occurs starting from $\mathrm{pH}$ values of 3.5 to 4 . At more elevated $\mathrm{pH}$ values, starting from $\mathrm{pH} 4.8$, the solution becomes oversaturated towards both $\mathrm{Al}$ and $\mathrm{Si}$ and allophane starts to precipitate (Ugolini \& Dahlgren, 2002; Theng \& Yuan, 2008). As demonstrated by the almost perfect segregation of both layers, the Fe in solution must have been almost entirely depleted before $\mathrm{Al}$ precipitation.

Although it seems thermodynamically more logic that the gel phases were precursors for the more crystalline halloysite and goethite (Farmer et al., 1991; Harsh, 2000), the simultaneous precipitation of gel and crystalline products was described by Percival et al. (2000) and Churchman (2000). It is remarkable that in the borehole, gels are much more abundant than crystalline phases (Table 4). This could suggest a sequential crystallization but more likely reflects the difference in $\mathrm{pH}-\mathrm{Eh}$, moisture conditions and accommodation space between the borehole, intersecting an undisturbed stratiform succession and the doline exposed for centuries in the underground quarry. Parfitt (2009) indicated that the supply of infiltration water determines which mineral precipitates: enhanced water infiltration is believed to result in the preferential formation of allophane over halloysite (Huang, 2011).

\subsection{Analogous karstified sand-carbonate contacts}

Numerous halloysite occurrences in or at the contact of karstified lithologies have been reported in literature, several of which in Belgium(Davies \& Moore, 1957; Dupuis \& Ertus, 1995; Goemaere \& Hanson, 1997; Perruchot et al., 1997; Simon-Coinçon et al., 1997; De Putter et al., 2002; Melka et al., 2000; Polyak \& Güven, 2000; Perruchot et al., 2001; Kempe \& Werner, 2003; Kempe et

\begin{tabular}{|c|c|c|c|c|c|c|c|c|c|c|c|}
\hline & $\begin{array}{l}\mathrm{SiO}_{2} \\
(\%) \\
\end{array}$ & $\begin{array}{c}\mathrm{Al}_{2} \mathrm{O}_{3} \\
(\%) \\
\end{array}$ & $\begin{array}{c}\mathrm{Fe}_{2} \mathrm{O}_{3} \\
(\%) \\
\end{array}$ & $\begin{array}{l}\mathrm{CaO} \\
(\%) \\
\end{array}$ & $\begin{array}{l}\mathrm{K}_{2} \mathrm{O} \\
(\%) \\
\end{array}$ & $\begin{array}{c}\text { MgO } \\
(\%) \\
\end{array}$ & $\begin{array}{c}\text { MnO } \\
(\%) \\
\end{array}$ & $\begin{array}{l}\mathrm{NaO} \\
(\%) \\
\end{array}$ & $\begin{array}{c}\mathrm{P}_{2} \mathrm{O}_{5} \\
(\%) \\
\end{array}$ & $\begin{array}{l}\mathrm{TiO}_{2} \\
(\%) \\
\end{array}$ & $\begin{array}{l}\text { LOI } \\
(\%) \\
\end{array}$ \\
\hline RAD19 & 38.22 & 34.14 & 1.31 & 1.36 & 0.27 & 0.13 & 0.00 & 0.19 & 0.79 & 0.03 & 22.35 \\
\hline RAD21 & 39.83 & 37.23 & 0.50 & 1.17 & 0.10 & 0.04 & 0.00 & 0.22 & 0.40 & 0.01 & 18.78 \\
\hline RAD25 & 38.90 & 35.03 & 1.61 & 1.66 & 0.07 & 0.19 & 0.01 & 0.18 & 0.45 & 0.01 & 19.13 \\
\hline
\end{tabular}

Table 4. Major element chemical composition of three white clay samples from the Hinnisdael VI quarry. 


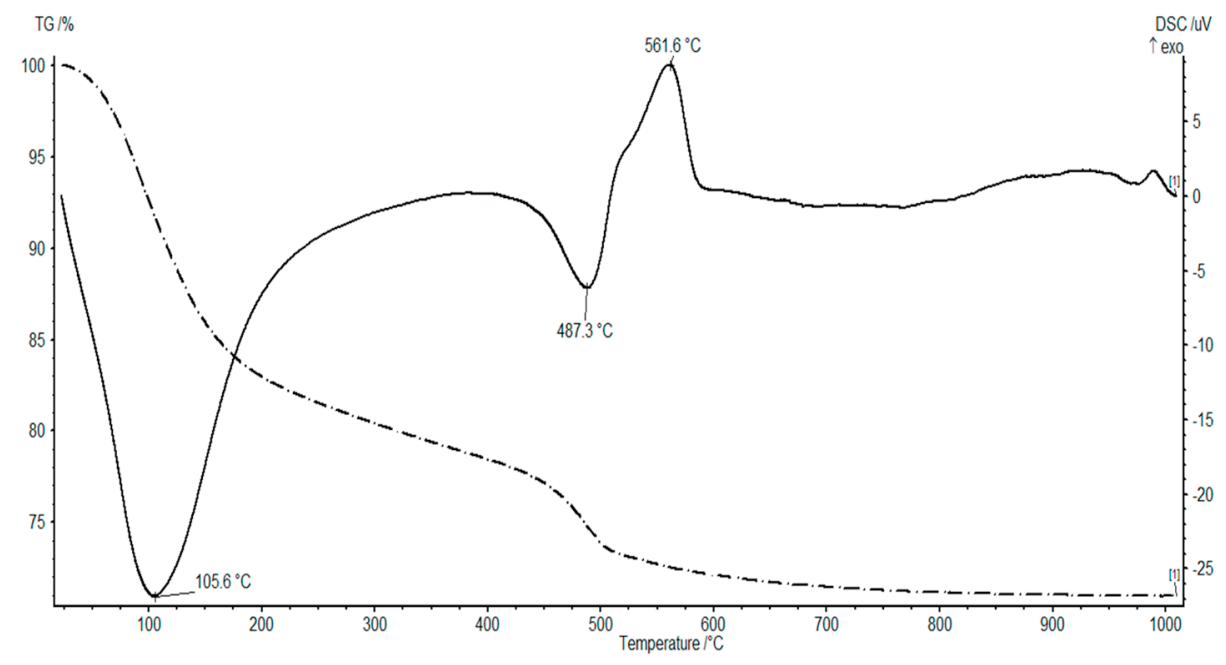

Figure 8. Simultaneous TGA (dotted line) - DSC (full line) analysis showing a dehydration peak at $105.6{ }^{\circ} \mathrm{C}$ for halloysite and dehydroxylation at $487.3^{\circ} \mathrm{C}$. The exothermic peak at 561.6 ${ }^{\circ} \mathrm{C}$ is caused by the transformation of allophane into a crystalline phase.

al., 2003; Maksimović, 2003). However, precipitation products are rarely pure and segregation of precipitation products is very uncommon. In most cases, halloysite was precipitated with other minerals such as gibbsite and kaolinite (Bruyère, 2004; Buurman \& Van der Plas, 1968) or kaolinite, alunite and goethite (Baioumy \& Hassan, 2004).

Buurman et al. (1975) described halloysite in the Curfs quarry (Valkenburg, The Netherlands) at a location approximately $35 \mathrm{~km}$ $\mathrm{NE}$ of Vechmaal, in a nearly identical stratigraphical interval as the Hinnisdael VI setting. The authors reported pockets of the monomineralic allophane inside Danian calcarenite (Geulhem Member of Houthem Formation) (Table 1) and halloysite-gibbsite precipitation at the contact with the Oligocene sand cover. Additionally, also alunite was reported during mineralogical analysis. Remarkably, no Fe-rich precipitation products are encountered at this site pointing towards the absence of $\mathrm{Fe}$ mobilization and thus slightly different mechanisms of formation compared to the Hinnisdael VI neogenesis products. The main difference between both sites is that the Curfs quarry probably remained under permanent meteoric conditions between the Danian and the Oligocene, while the Hinnisdael quarries have witnessed two phases of meteoric weathering, separated by a marine transgression depositing sediments of the Heers Formation during the Paleocene.

Clearly, the activity of $\mathrm{Si}$, or better the ratio of $\mathrm{Si}: \mathrm{Al}$, prescribes which alumina-based end products are being formed. Gibbsite formation requires high $\mathrm{Al}$ and very low Si activities compared to halloysite. This of course all depends on the nature and amount of the minerals present in the host formation and the local $\mathrm{pH}$-Eh conditions of the mobilization.

The mobilized iron in Vechmaal Hinnisdael VI doline therefore most likely originates from the dissolution of glauconite - remnants of which are still observed in the glauconite-rich sand patches at the sand-calcarenite contact. This points a very short distance process of dissolution and subsequent precipitation. In the Curfs quarry, the glauconite-enriched sand is absent (Buurman et al., 1975). The dissolved Al-Si ratio furthermore was very different which resulted in more favorable conditions for gibbsite precipitation. An analogous white halloysite precipitate at the contact of Grimmertingen sand and chalk was also observed at Vroenhoven, positioned between Vechmaal and Valkenburg, during the excavations for the enlargement of the Albert Canal in the eighties (observed by one of the authors N.V.).

\subsection{Timing of formation}

Precipitation of the halloysite-allophane and the goethiteferrihydrite postdates the early Oligocene sedimentation phase of the marine Grimmertingen sands, which provide the host rock, but predates the end of the karstification and formation of the doline, since the halloyite layer has been displaced and brecciated. Karstic dissolution of the top of the Cretaceous calcarenite was certainly stopped before the deposit of calcareous loess layers during the Pleistocene. Moreover, the endokarstic features observed were formed in the phreatic zone, preceding regional uplift and river incision (Willems et al., 2007). Karstification, hence precipitation, therefore is pre-Quaternary. Strong continental weathering is generally associated with peneplanation during long periods of warm climate and relatively shallow groundwater levels (Buurman \& Van der Plas, 1968; Buurman, 1972; Demoulin, 2003, 2006). Hence, the most likely time for the halloysite precipitation is the Miocene (Van den Broek \& Van der Waals, 1967; Yans, 2003; Quesnel et al., 2006).

\section{Conclusion}

The sand-calcarenite contact of the Hinnisdael VI cave is characterized by the authigenic precipitation of halloysiteallophane and goethite-ferrihydrite. Although their occurrence is discontinuous and often disturbed by secondary faulting and brecciation, the purity and almost perfect segregation of both precipitations is remarkable. Halloysite was found to be present in its hydrated $10 \AA$ form in the sediment, but quickly alters to the dehydrated $7 \AA$ form in normal room conditions. Halloysite was systematically encountered together with allophane, a semicrystalline gel phase which probably, because of its difficult identification, occurs more frequently in halloysite settings than currently reported. Oxidation of pyrite to jarosite and goethite in the overlying Grimmertingen sand Member caused substantial acidification of the percolating water resulting in close-range dissolution of glauconite and other silicates and precipitation at the sand-calcarenite contact. It was furthermore shown that an apparent marginal difference in stratigraphy between Vechmaal and the Curfs quarry in Valkenburg, i.e. the absence of a marine incursion having deposited the thin glauconite-enriched sand, changes the process conditions resulting in the precipitation of gibbsite, alunite, allophane and halloysite at the Curfs quarry in Valkenburg whereas no iron precipitation products are formed.

\section{Acknowledgments}

The authors are grateful for the reviews of Dr. Annick Anceau and Dr. Eric Goemaere who provided constructive remarks and suggestions to the manuscript. The authors wish to thank Dr. Nancy Weyns, Dr. Elvira Vassilieva and Ria Brepoels for their much appreciated help with the laboratory analyses.

\section{References}

Adamo, P., Violante, P. \& Wilson, M.J., 2001. Tubular and spheroidal halloysite in pyroclastic deposits in the area of the Roccamonfina volcano (Southern Italy). Geoderma, 99/3-4, 295-316.

Adriaens, R., Vandenberghe, N. \& Elsen, J., 2014. Natural clay-sized glauconite in the Neogene deposits of the Campine basin (Belgium). Clays and Clay Minerals, 62, 35-52.

Adriaens, R., 2015. Neogene and Quaternary clay minerals in the southern North Sea. Unpublished PhD thesis. KULeuven, 272 p. 
Bailey, S.W., 1980. Structures of layer silicates. In Brindley, G.W. \& Brown, G. (eds), Crystal Structures of Clay Minerals and their X-ray Identification. Mineralogical Society, London, Monograph 5, 1-123.

Baioumy, H.M. \& Hassan, M.S., 2004. Authigenic halloysite from ElGideda iron ore, Bahria Oasis, Egypt: characterization and origin. Clay Minerals, 39, 207-217.

Bruyère, D., 2004. Néogenèses silico-alumineuses en contexte cryptokarstique: l'halloysite de Beez (Namur, Belgique) et de Aïn Khamouda (Kasserine, Tunisie). Unpublished $\mathrm{PhD}$ thesis. Université de Mons, Département mines-géologie, 231 p.

Buurman, P., 1972. Paleopedology and stratigraphy of the Condrusian peneplain (Belgium), with a reconstruction of a paleosol. Centre for Agricultural Publishing and Documentation, Wageningen, $67 \mathrm{p}$.

Buurman, P. \& Van der Plas, L., 1968. The occurrence of halloysite and gibbsite in peneplain deposits of the Belgian Condroz. Geologie en Mijnbouw, 47, 345-348.

Buurman, P., Boekschoten, G.J. \& Koster, Y., 1975. Allophane and its initial crystallization products as concretions in the South Limburg chalk. Geologie en Mijnbouw, 54, 36-42.

Churchman, G.J., 2000. The alteration and formation of soil minerals by weathering. In Sumner, M.E. (ed.), Handbook of soil science. CRC press, Boca Raton, Florida, F3-F76.

Chorover, J., DiChiaro, M.J. \& Chadwick, O.A., 1999. Structural charge and cesium retention in a chronosequence of tephritic soils. Soil Science Society of America Journal, 63, 169-177.

Claes, S. \& Gullentops, F., 2001. Kaartblad (33) Sint-Truiden. Schaal 1:50 000. Toelichtingen bij de geologische kaart van België - Vlaams Gewest, Kaartblad 33, Sint-Truiden. Belgische Geologische Dienst \& Ministerie van de Vlaamse Gemeenschap, Afdeling Natuurlijke Rijkdommen en Energie, Brussel, 67 p.

Davis, D. \& Moore, G.W., 1957. Endellite and hydro-magnesite from Carlsbad Caverns. National Speleological Society Bulletin, 19, 24 27.

Demoulin, A., 2003. Paleosurfaces and residual deposits in ArdenneEifel: historical overview and perspectives. Géologie de la France, 2003/1, 17-21.

Demoulin, A., 2006. La néotectonique de l'Ardenne - Eifel et des régions avoisinantes. Académie royale de Belgique, Mémoires de la Classe des Sciences, 25, $252 \mathrm{p}$.

De Putter, Th., André, L., Bernard, A., Dupuis, Ch., Jedwab, J., Nicaise, D. \& Perruchot, A., 2002. Trace element (Th, U, Pb, REE) behaviour in a cryptokarstic halloysite and kaolinite deposit from Southern Belgium: importance of "accessory" mineral formation for radioactive pollutant trapping. Applied Geochemistry, 17, 1313-1328.

Dupuis, C. \& Ertus, R., 1995. The karstic origin of the type halloysite in Belgium. In Churchman, J., Fitzpatrick, R.W. \& Eggleton, R.A. (eds), Clays Control the Environment. Proceedings of the $10^{\text {th }}$ International Clay Conference 1993 (G), Adelaide, Australia, 262-266.

Dusar, M., Lagrou, D., Willems, L., Felder, P.J. \& Matthijs, J., 2005. De mergelgrotten van Hinnisdael te Vechmaal (gemeente Heers, Limburgs Haspengouw), een geologische bijdrage tot de studie van het Krijt. Geological Survey of Belgium Professional Paper, 301, 89 p.

Dusar, M. \& Lagrou, D., 2007. Lithofacies and paleogeographic distribution of the latest Cretaceous deposits exposed in the Hinnisdael underground quarries in Vechmaal (Commune Heers, Belgian Limbourg). Geologica Belgica, 10/3-4, 176-181.

Farmer, V.C., McHardy, W.J., Palmeli, F., Violante, A., \& Violante, P., 1991. Synthetic allophanes formed in calcareous environments: Nature, conditions of formation and transformation. Soil Science Society of America Journal, 55, 1162-1166.

Fields, M. \& Claridge, G.G.L., 1975. Allophane. In Gieseking, J.E. (ed.), Soil Components, Vol. 2. Springer-Verlag, Heidelberg, 351-393.

Goemaere, E. \& Hanson, A., 1997. New data about the halloysite from Angleur type-locality, Belgium. Geologica Carpathica, Series Clays, $6 / 1,11-25$.

Harsh, J., 2000. Poorly crystalline aluminosilicate clays. In Sumner, M.E. (ed.), Handbook of soil science. CRC Press, Boca Raton, Florida, F169-F182.

Hill, C.A., 2000. Overview of geologic history of cave development in the Guadalupe Mountains, New Mexico and west Texas. Journal of Cave and Karst Studies, 62/2, 60-71

Huang, Pan Ming, Li, Yuncong \& Sumner, M.E. (eds), 2011. Handbook of soil sciences: Properties and processes. $2^{\text {nd }}$ ed. CRC Press, Taylor \& Francis Group, Boca Raton, Florida, 1442 p.

Jackson, M.L., 1975. Soil chemical analysis - Advanced course. $2^{\text {nd }}$ ed. Published by the author, Madison, Wisconsin, $895 \mathrm{p}$

Joussein, E., Petit, S., Churchman, J., Theng, B., Righi, D. \& Delvaux, B., 2005. Halloysite clay minerals - A review. Clay Minerals, 40, 383-426.

Keeling, J.L., 2015. The mineralogy, geology and occurrences of halloysite. In Pasbakhsh, P. \& Churchman, G.J. (eds), Natural Mineral Nanotubes: Properties and Applications. Apple Academic Press Inc., Oakville, ON, 96-115.
Kempe, S. \& Werner, M.S., 2003. The Kuka'iau Cave, Mauna Kea, Hawaii, created by water erosion: A new Hawaiian cave type. Journal of Cave and Karst Studies, 65, 53-67.

Kempe, S., Bauer, I. \& Henschel, H.V., 2003. Pa'auhau civil defense cave on Mauna Kea, Hawaii - a lava tube modified by water erosion. Journal of Cave and Karst Studies, 65, 76-85.

Kloprogge, J.T. \& Frost, R.L., 1999. Infrared emission spectroscopy study of the dehydroxylation of $10 \AA$ halloysite from a Neogene cryptokarst of south Belgium. Geologica Belgica, 2/3-4, 213-220.

Maksimović, Z.J., 2003. An unknown Ni-Al hydrosilicate. Acta Geologica Hungarica, 46, 313-320.

Melka, K., Suchý,V., Zeman, A., Bosák, P. \& Langrová, A., 2000. Halloysite from karst sediments of the Konĕprusy area: Evidence for acid hydrothermal speleogenesis in the Bohemian Karst, Czech Republic. Acta Universitatis Carolinae, Geologica, 44, 117-124.

Nicaise, D., 1998. L'halloysite des cryptokarsts néogènes de l'EntreSambre-et-Meuse (Belgique) : synthèse géologique, minéralogique et géochimique. Unpublished $\mathrm{PhD}$ thesis. Université de Paris-Sud, $145 \mathrm{p}$.

Papoulis, D., Tsolis-Katagas, P., Kalampounias, A.G. \& Tsikouras, B., 2009. Progressive formation of halloysite from the hydrothermal alteration of biotite and the formation mechanisms of anatase in altered volcanic rocks from Limnos Island, Northeast Aegean Sea, Greece. Clays and Clay Minerals, 57/5, 566-577.

Parfitt, R.L., 2009. Allophane and imogolite: role in soil biogeochemical processes. Clay minerals, 44/1, 135-155.

Percival, H.J., Parfitt, R.L. \& Scott, N.A., 2000. Factors controlling soil carbon levels in New Zealand grasslands: Is clay content important? Soil Science Society of America Journal, 64, 1623-1630.

Perruchot, A., Dupuis, C., Brouard, E., Nicaise, D. \& Ertus, E., 1997. L'halloysite karstique: comparaison des gisements types de Wallonie (Belgique) et du Périgord (France). Clay Minerals, 32, 271-287.

Perruchot, A., Dupuis, C., De Putter, T., Nicaise, D. \& Arbey, F., 2001. Paragenèses silico-alumineuses précoces d'âge Quaternaire en contexte cryptokarstique (Haute-Normandie, France) ; implications pour l'argilogenèse. Comptes Rendus de 1'Académie des Sciences, Series IIA Earth and Planetary Science, 332/5, 315-322.

Polyak, V.J. \& Güven, N., 2000. Clays in caves of the Guadalupe Mountains, New Mexico. Journal of Cave and Karst Studies, 62/2, 120-126.

Quesnel, F., Yans, J., Dupuis, C., Wyns, R., Théveniaut, H. \& Demoulin, A., 2006. Paléoaltérations mésozoïques et cénozoïques en Ardenne et ses bordures: caractérisation, datation et reconstitution géométrique des paléosurfaces associées et analyse de leurs déformations successives. Géologie de la France, 2006/1-2, 99-102.

Ronchi, B., 2009. Hydrogeologische karakterisatie en modellering van de onverzadigde zone in het tufkrijt van de Maastricht Formatie te Vechmaal (Zuid-Limburg). Unpublished M.Sc. thesis. KU Leuven, Earth \& Environmental Sciences, $166 \mathrm{p}$

Sherman, G.D., 1952. The genesis and morphology of the alumina-rich laterite clays (Hawaii). In Problems of clay and laterite genesis. American Institute of Mining and Metallurgical Engineers, annual meeting symposium, Feb. 1951, 154-161.

Sheets, J.M. \& Tettenhorst, R.T., 1997. Crystallographic controls on the alteration of microcline perthites from the Spruce Pine District North Carolina. Clays and Clay Minerals, 45, 404-417.

Simon-Coinçon, R., Thiry, M. \& Schmitt, J.-M., 1997. Variety and relationships of weathering features along the early Tertiary palaeosurface in the southwestern French Massif Central and the nearby Aquitaine Basin. Palaeogeography, Palaeoclimatology, Palaeoecology, 129, 51-79.

Snellings, R., Machiels, L., Mertens, G. \& Elsen, J., 2010. Rietveld refinement strategy for quantitative phase analysis of partially amorphous zeolitized tuffaceous rocks. Geologica Belgica, 13, 183-196.

Środoń, J., Drits, V.A., McCarty, D.K., Hsieh, J.C.C. \& Eberl, D.D., 2001. Quantitative XRD analysis of clay-rich rocks from random preparations. Clays \& Clay Minerals, 49, 514-528.

Suhr, N.H. \& Ingamells, C.O., 1966. Solution technique for analysis of silicates. Analytical Chemistry, 38, 730-734.

Theng, B.K.G. \& Yuan, G., 2008. Nanoparticles in the soil environment. Elements, 4, 395-399.

Ugolini, F.C. \& Dahlgren, R.A., 2002. Soil development in volcanic ash. Global Environmental Research, 6, 69-81.

Van Breemen, N. \& Buurman, P., 2002. Soil formation. Kluwer Academic Publishers, Dordrecht, 407 p.

Van den Broek, J.M.M. \& Van der Waals, L., 1967. The Late Tertiary peneplain of South Limburg (The Netherlands). Silicifications and fossil soils; a geological and pedological investigation. Soil Survey Papers, 3, 1-24.

Vaughan, R.G., Calvin, W.M., Hook, S.J. \& Taranik, J.V., 2002. Mapping acid sulfate alteration of basaltic andesite with thermal infrared data. Lunar and Planetary Science, 33, 1153-1154. 
Velde, B. \& Meunier, A., 2008. The origin of clay minerals in soils and weathered rocks. Springer, Berlin, $406 \mathrm{p}$.

White, R.E., 1979. Introduction to the Principles and Practice of Soil Science. Blackwell, London, 198 p.

Willems, L., Rodet, J., Fournier, M., Laignel, B., Dusar, M., Lagrou, D., Pouclet, A., Massei, N., Dussart-Baptista, L., Compère, Ph. \& Ek, C., 2007. Polyphase karst in Cretaceous chalk and calcarenite of the Belgian-Dutch border. Zeitschrift für Geomorphologie N.F., 51/3, 361-376.

Yans, J., 2003. An overview of the saprolites of Belgium and their potential kaolinitic supplies to Mesozoic and Cainozoic sediments. Géologie de la France, 2003/1, 33-37.

Yuan, P., Tan, D. \& Annabi-Bergaya, F., 2015. Properties and applications of halloysite nanotubes: recent research advances and future prospects. Applied Clay Science, 112-113, 75-93.

Yuan, P., Thill, A. \& Bergaya, F., 2016. Nanosized tubular clay minerals: Halloysite and Imogolite. Elsevier, Amsterdan, Developments in Clay Science, 7, 754 p. 